\title{
Local Wisdom of Rice Harvest in Citorek Indigenouscommunities
}

\author{
$1^{\text {st }}$ Tjut Afrida \\ STKIP Setiabudhi Rangkasbitung \\ Indonesia \\ $4^{\text {th }}$ Gita Rizkiyah \\ SMPN 3 Cibeber \\ Banten, Indonesia \\ $7^{\text {th }}$ Dine Trio Ratnasari \\ STKIP Setiabudhi Rangkasbitung \\ Indonesia
}

\author{
$2^{\text {nd }}$ Rian Fauzi \\ STKIP Setiabudhi Rangkasbitung \\ Indonesia \\ rianfauzi.stkipsb@gmail.com \\ $5^{\text {th }}$ Usmaedi \\ STKIP Setiabudhi Rangkasbitung \\ Indonesia \\ $8^{\text {th }}$ Anggi Rahmani \\ STKIP Setiabudhi Rangkasbitung \\ Indonesia
}

\author{
$3^{\text {rd }}$ Weny Widyawati Bastaman \\ STKIP Setiabudhi Rangkasbitung \\ Indonesia \\ $6^{\text {th }}$ Habib Cahyono \\ STKIP Setiabudhi Rangkasbitung \\ Indonesia
}

Abstract-Farming in Citorek still use local wisdom which has a tradition or regulation that must be followed by communities. The custom kept by the Citorek villagers is planting the rice use traditional tools and all the communities agree not use modern tools at all. The periode of planting is annual event and and it is done on Monday. The role of farming system in" Kasepuhan Citorek" is still regulated from planting to harvest by customs. This system is trusted and run by Citorek community. This system is more superior than the system offered by local government about 2 or 3 times in a year. The harvestare used for custom needs. A research method uses a qualitative by interview, document, and study literature. The farming system governed by custom from the determination of the "tangtu" rice fields. The cultivation of "tangtu" rice fields is carried out by indigenous people who are driven by "Jaroadat" through the head village to work together. The names of the activities of them are ngagalengan/mopog,macul/nyangkul, nyogolan, musyawarahtibabinih, tebar/sebar, cabut, Tandur, ngoyos1/ Ngaramet, babad, ngoyos2, mapag pare beukah, mipit, dibuat, ngalantay/moe. ngunyal/ rengkongasupleuit, Nganyaran, Badamianserentahun. These system are undergone by the people until now and to start the activity the people determine "tangtu" rice field.

Keywords-Local Wisdom, Rive Harvest, Indigenouscommunities

\section{INTRODUCTION}

Farming is an activity of utilizing biological resources by humans to produce food, obtain food from cultivation on their land or from forests and land. Farming can serve as a benchmark for economic growth in developing countries. One of the potential mechanisms for increasing farming crop is the use of improved farming technology, such as fertilizer, seeds and planting techniques. [1] Many of these crops can be stored as food supplies in which it is as a part of community management, nature and community life patterns as inherited by ancestors.
Citorek Indigenous communities have an understanding that if preserving the heritage of ancestors means respecting their ancestors. They do not recognize the advantages of the new system compared to the traditional cultural system, they can accept a new culture from outside as long as it does not conflict with traditional values. Customs have strong ties and influence in the community, it means that binding power depends on the people who support these customs. [2] so that between modern life and tradition there is still a generation that inherits it. They realize that when the current of rapid modernization is not anticipated, they can be protected by their cultural identity as indigenous people. [3]

Food is a necessity of physical life provided by nature. Many local communities practice this, residents are able to adapt to the climate and weather by developing food and farming systems. The majority of communities work as farmers. Farming is traditionally managed and uses a traditional system that has been maintained until now. The farming planning strategy implemented by the traditional Citorek community invites researchers' questions to conduct research, both on traditional custom social life and farming patterns. The farming pattern carried out by the Citorek community is local wisdom that must be preserved because the farming pattern in Citorek is environmentally friendly and the harvest is proven to be a model for other regions to produce superior rice.Local wisdom in a community view, life way wisely and rightly, is expressed through traditional rituals. Local wisdom in this perspective is a product of spiritual perfectness in aseveral centuries in relations between people from the same culture. This is related to the concept of God, and human relationships with God, and relationships with nature and self. [4]

Local wisdom is a values system and way of life of a particular community in interacting with its environment, 
namely social and moral values that exist in the community associated with social interaction and nature balancing.[5] Local wisdom can beunderstood as ideas, values, local viewswisely, full of wisdom, good values, embedded and followed by certain communitymembers. [6] Thus, local wisdom must be interpreted as a spirit that continues to live in the community. Culture is a way of life that is developed and shared by a group of people passed down from generation to generation.[7] besides, local wisdom can also be a symbol and symbolic interaction that comes from the interaction between people and elements of local wisdom. Through symbols, people will think more and recognize meaning wisely.[8] Further more local wisdom can also be interpreted as the community has its own culture, is a small community with a production system, resource management, health systems, knowledge and learning systems, justice systems, self-government, and economic systems run by each family and community.[9]

Local wisdom must be interpreted as a spirit that continues to live among rural communities. Culture is a way of life that is developed and shared by a group of people passed down from generation to generation. [10]As communitythatoccupies a traditional village, Citorek village community can still be grouped into traditional communities. Where a group of people who still maintain the tradition of their ancestors as a way of everyday life, although not a few people who have followed the development of the day in their daily lives. But still maintaining tradition. various habits, ways of life, values, language, and spiritual life. Local traditions are preserved in the community as an identity, in which local cultural values contained in the tradition are used as guidelines, believed to be truth and sacredness by the community. Cultural values then shape local wisdom which is reflected in the concept of social solidarity in carrying out its activities. [11]The Citorek indigenous people still hold on to the traditions of their ancestors since the Village was formed. The understanding that culture is the result of human learning through life experiences by interacting with their social environment is summarized in the concept of culture. [12]Local knowledge is defined as follows: 1) knowledge related to the place, and a range of experiences, and developed by the local community; 2) knowledge acquired through mimicry, imitation, and experiment; 3) daily practical knowledge gained from trial and error; 4) empirical knowledge is not theoretical; 5) comprehensive and integrated knowledge in the fields of tradition and culture.[13]

The "Wewengkon adat Kasepuhan Citorek" is also one of the cultures between Moslem communities and the cultural patterns of the Kasepuhan community system. Citorek gives the characteristic of a community of life that adheres to the social system that forms a Moslem community and this is what distinguishes between "Kaolotan and Kasepuhan".

\section{RESEARCH METHODOLOGY}

In a scientific study, to solve a problem it is very necessary to have a research method to determines the success of the study. The method used in this research is using qualitative methods. The qualitative method is often called naturalistic because the research is conducted in natural conditions (natural setting) or it also called the ethnographic methods because it is often used research in the field of anthropology and culture. [14]Qualitative researchers rely on informants to provide in-depth responses to questions about how they build or understand their experiences. By doing a humanistic and interpretive approach, it is expected to get understanding and information on data sources to support research. Thus, qualitative researchers will get more information about a phenomenon[15].It is also supported by an exploratory approach that puts the research finding new ideas to deepen the knowledge of the events, certain symptoms, social phenomena, and explain the occurrence of the phenomenon. [16] Exploration Research is an exploration activity to understand the problem or topic. Research data obtained through field observations, interviews, and documents.In conducting research interviews, researchers provide opportunities to create and capture deep insights and levels of focus that are rarely achieved through surveys, observational studies. [17]

\section{RESEARCH RESULTS AND DISCUSSION}

\section{A. Farming in Citorek}

"Kasepuhan Citorek" is a part of the southern Lebak Regency that is included in the Cibeber Subdistrict area. The distance between "Kasepuhan Citorek" and the Subdistrict city is $30 \mathrm{Km}$. Through the old road to the south, it can be reached by using a vehicle or motorcycle with bad road conditions. To be able to arrive in the regency city (Rangkasbitung) through the southern route, the distance must be around $180 \mathrm{Km}$. This is quite difficult and tiring. While the distance between Citorek and Lebak Regency through the northern route is around $50 \mathrm{Km}$, with a reasonably good road condition that allows its users to trace this road to Citorek comfortably.

The boundaries of "Wewengkon Kasepuhan Citorek" region are from the Bio Environment Affair. [18] As follows:

TABLE I. BORDERLINE

\begin{tabular}{|l|l|}
\hline Area & Boundary \\
\hline North & $\begin{array}{l}\text { Kendeng Mountain which borders with } \\
\text { SobangSubdistrict. }\end{array}$ \\
\hline South & PasirSoge which borders with Cihambali Village \\
\hline West & $\begin{array}{l}\text { Nyungcung Mountain which borders with Cibedug } \\
\text { indigenous communities }\end{array}$ \\
\hline East & $\begin{array}{l}\text { ParakanSaat / Batu Muengpeukwhich borders withCisitu } \\
\text { Village. }\end{array}$ \\
\hline
\end{tabular}


The results of observations and data obtained for the total area of Citorek indigenous community are divided based on the Citorek Kasepuhan data. The total of "Kasepuhan Citorek" areas are:

TABLE II. AN AREA

\begin{tabular}{|l|l|}
\hline Area & Boundary \\
\hline Central Citorek Village & $: 2.222 \mathrm{Ha}$ \\
\hline EastCitorek Village & $: 1.713 \mathrm{Ha}$ \\
\hline SouthCitorek Village & $: 2.125 \mathrm{Ha}$ \\
\hline West Citorek Village & $: 2.222 \mathrm{Ha}$ \\
\hline SabrangCitorekVillage & $: 1.699 \mathrm{Ha}$ \\
\hline Total & $: 9.469 \mathrm{Ha}$ \\
\hline
\end{tabular}

In the Village Regulation also formed an institutional structure like those in "Kasepuhan". This is part of the decentralized function of "Kasepuhan's" power. In implementing the institutional structure in the village, it must be a custom figure or "kokolot" who has the mandate to lead the village in the context of custom institutions. It also has the function as a mediator for each result of discussion at the center of "Kasepuhan", and can also be a village partner in implementing programs for the welfare of the community.

\section{B. Local Wisdom-Based Farming in Citorek}

"Local Wisdom" is the etymological absorption of English. In the definition of Quaritch Wales, local wisdom is defined as the ability of local culture to deal with the influence of foreign culture when the two cultures are interconnected. local is the condition of a place or locality, while wisdom is a trait attached to a person's character, which means wise. It has very broad definitions or meanings if combined, especially matters related to the order of values, habits, and traditions.

There are procedures for cultivating rice fields that have existed from long ago, which starts from the
"Tangtu" rice fields. It also can be interpreted as traditional rice fields of "Kasepuhan Citorek". The cultivation of this "Tangtu" rice field is carried out by the indigenous community that is organized by "Jaro Adat" through the Headman to work together and the results are used for the activities or customary needs. Before the commencement of the cultivation of the paddy fields, the "Kasepuhan" discussion is conducted regarding the right time to start "asup leuweung" (cultivation of rice fields and dry rice field, gardening or other farming). It is a package with seren taun (turning year).Traditional leaders' thought can be seen as a unit that is motivated by the community, external forces (ancestors) and internal forces (traditional leaders). [19]

Based on the research results conducted through interviews and observations in the field, that the initial process to the end of the rice is carried out in stages in several stages which have become the provisions of the "Kasepuhan Citorek" community to work on farming land. These stages include:

TABLE III. CITOREK KASEPUHAN AGRICULTURAL STRAGE SYSTEM

\begin{tabular}{|c|c|}
\hline Activities & Meaning \\
\hline Ngagaleungan / Mopog & $\begin{array}{l}\text { Its use is to correct or tidy up boundaries or rice field bunds that are boundaries with other } \\
\text { fields. }\end{array}$ \\
\hline Macul / Nyangkul & Macul/nyangkulconcerning "macul badag" and "macul alus" in the rice fields \\
\hline Nyogolan & $\begin{array}{l}\text { To flatten the entire surface of the paddy fields (parts of the paddy fields) that have not been } \\
\text { leveled, so that later they will be suitable for planting good soil and make rice fertile }\end{array}$ \\
\hline MusyawarahTibaBinih & "Baris Kolot" Discussion to determine the spread time (spread) \\
\hline Tebar / Sebar & Growing rice seedlings in a nursery or seedling nurseries early planting \\
\hline Cabut & $\begin{array}{l}\text { Picking up seedlings at the nursery to be planted, usually the rice fields are different from the } \\
\text { rice fields to be planted }\end{array}$ \\
\hline Tandur & spreading planting seeds that have been prepared in advance \\
\hline Ngoyos 1 / ngaramet & Cleanse the rice fields from pests and grasses that disturb the growth process of rice plants \\
\hline Babad & $\begin{array}{l}\text { This activity is usually carried out when the grass around the rice fields interferes with the } \\
\text { growth of rice plants, so the cleaning is done }\end{array}$ \\
\hline Ngoyos 2 & Cleaning activities of plants and grasses that inhibit the growth of rice plants \\
\hline Mapag Pare Beukah & $\begin{array}{l}\text { "Mapag" means to greet, while the "Pare" means rice, and "Beukah" is directed to the rice } \\
\text { that is contained before the rice bow. The implementation of Mapag Pare Bekah is usually } \\
\text { carried out when planting rice which is only } 3-4 \text { months old, by preparing flour, sugar. The } \\
\text { material is presented in the form of "dodol" which is distributed to all communities as the } \\
\text { laden of fortune during planting to the harvest. }\end{array}$ \\
\hline Mipit & "Mipit" is a procession of traditional ceremonies to start the harvest. \\
\hline Dibuat / panenpadi & Harvest picking / picking rice that is ripe. The harvesting uses "etem / ani-ani" \\
\hline Ngalantay/moe & Drying the rice after harvesting on the floor \\
\hline Ngunyal / Rengkong & $\begin{array}{l}\text { Transporting rice from "lantayan" / rice fields after "pocong". "Pocong" is a combination of } \\
\text { three bunches or rice keupeul into one called "pocong" }\end{array}$ \\
\hline AsupLeuit & Inserting dry rice from the clothesline / floor. \\
\hline Nganyaran & "Selametan" for newly harvested rice, and cooking rice into harvested rice that year \\
\hline Badamianserentaun & eration for "seren taun" even \\
\hline
\end{tabular}


Harvesting is the final work of crop cultivation, but it is the beginning of post-harvest work, which is to prepare for storage or marketing. [20] From rice planted to rice harvest, there are various kinds of traditions or rituals carried out, namely: "asupleuweung", "mapag pare beukah", "syukuranmipit", "serentaun". "SerenTaun"is the last tradition of the process, as a form of thanksgiving for the gift of nature. Besides rice is a human life partner, it is a human obligation to continue to care for it, since it was planted in the fields until the time of harvest later.

Citorek indigenous communities believe that land needs to be restored to achieve the balance and harmony of nature. Rice farming may not use chemicals, except using materials available in nature. With a variety of local wisdom, "Kasepuhan Citorek" still preserves the tradition of farming until now by providing knowledge of local wisdom to the next generation.

\section{The Role of Local Wisdom-Based Farming Systems in Citorek}

The role of the farming system in "Kasepuhan Citorek" is still regulated by custom, from planting to harvest. This system is still trusted and run by the Citorek community. This farming system is a farming system that is superior to the local government's recommended farming system with a harvest system 2-3 times a year. It is governed by customs from the determination of the "tangtu" rice fields. The cultivation of "tangtu" rice fields is carried out by indigenous people who are driven by "Jaro" through the Headman of the village to work together.

Different from other farming patterns, the rice harvest cycle in "Kasepuhan" is only done once a year for 6 months for the rest to be cultivated by cultivating the same gold fish for 6 months, so the Citorek community replaces their planting after planting rice by raising gold fish, the Citorek community assumes that the rice fields after being harvested with gold fish will make the fields soft and fertile so the Citorek community harvests twice but once by the rice harvest and 1 time by harvesting gold fish or called the Ngabedolken. The people believe that land needs to be restored to achieve natural balance and harmony. Rice farms may not use chemicals, except using materials available in nature. With a variety of local wisdom, then in KasepuhanCitorek there has never been an attack of rice as often pests occur in other places that practice intensive farming.

\section{CONCLUSION}

Farming in Citorekstill uses local wisdomin whicheveryplanting of ricehave traditionsthat all communities must follow theserules. The tradition stillcarried out by the Citorekcommunityis the planting of local ricewhich continues to use traditionaltools and followed by all the people there. Citorekcommunityfarmingisdominated by local riceplantingwith a cropperiod of once a year and all activities start only on Monday. This wasdonebecausebased on the customs of the Citorekcommunitywhichisstillbeingimplemented. The role of the farming system isstillregulated by tradition, fromplanting to harvest. This system isstilltrusted and run by them. Foodsecurity in the KasepuhanCitorek area isverydifferentfromotherregions. The values that have been adopted by the indigenous village community are not onlyrelated to the socio-cultural aspects, but alsointegratedwithother aspects such as the economic system, the environment and so on.

\section{REFERENCES}

[1] J. C. Aker, "Dial "A" For Agriculture a review of information and communication tecnologies for agricultural extension in developing countries," Agricultural Economics, vol. 42, no. 6, pp. 631-647, 2011.

[2] Muazzin, "Hak Masyarakat Adat (Indigenous Peoples) atas Sumber Daya Alam: Presfektif Hukum Internasional," Padjadjaran Jurnal Ilmu Hukum, vol. 1, no. 2, p. 328, 2014.

[3] R. W. I. D. Naniek Framanik, "Traditional Communication Model of Traditional Leaders in Maintaining Local Wisdom in Custom Tribe, Kasepuhan Cisungsang, South Banten, Banten Province, Indonesia," dalam International Conference on Democratisation in Southeast Asia (ICDeSA 2019, Serang Banten, 2011.

[4] A. J. Pesurnay, "Local wisdom in a new paradigm: Applying system theory to the study of local culture in Indonesia," IOP Conference Series : Earth and Evironmental Science, vol. 175, no. 1, p. 012037, 2018 .

[5] N. N. D. Ira Miranti, "Learning Local Wisdom for Character Education: an Insight from Choblong Sundanese Village in Indonesia," Jurnal Ilmiah Peuradeun, vol. 6, no. 3, pp. 409-426, 2018.

[6] N. G. D. R. Aan Hasanah, "Cultivating character education based on sundanese culture local wisdom," Jurnal Pendidikan Islam, vol. 2, no. 2, pp. 231-251, 2016.

[7] S. F. Bahari, "QUALITATIVE VERSUS QUANTITATIVE RESEARCH," Sains Humanika, vol. 52, no. 1, pp. 17-28, 2010.

[8] I. Meliono, "3. Understanding the Nusantara thought and local wisdom as an aspect of the Indonesian education," TAWARIKH, vol. 2, no. 2, pp. 221-223, 2011.

[9] R. Mungmachon, "Knowledge and Local Wisdom: Community Treasure," International Journal Of Humanities and Social Science, vol. 2, no. 13, pp. 174-180, 2012.

[10] A. Fadillah, Mokaha Urang Cisungsang, Serang: Dinas Kebudayaan Dan Parawisata Provinsi Banten, 2015.

[11] D. N. S. Ilham Rohman, "Local Wisdom of Kasepuhan Ciptagelar: The Development of Social Solidarity in The Era of Globalization," International Journal Of multicultural and Multireligious Understanding, vol. 5, no. 3, pp. 35-42, 2018.

[12] H. Ayatullah, Budaya dan Religi masyarakat Ciomas, Jakarta: Kultura, 2014.

[13] Dahlia, "Local Wisdom Inbuilt Environment in Globalization Era," Contemporary Research Center Publications, vol. 3, no. 6, pp. 158$165,2010$.

[14] P. D. Sugiono, Metode Penelitian Kuantitatif dan Kualitatif Dan R \& D, Bandung: Alfabeta, 2008.

[15] D. K. D. S. C. Ronald L Jackson, "What is qualitative research?," Qualitative research reports in communication, vol. 8, no. 1, pp. 21-28, 2007.

[16] B. Mudjiyanto, "Tipe Penelitian Eksploratif Komunikasi Exploratory Research Communication Study," STUDI KOMUNIKASI DAN MEDIA, vol. 22, no. 1, p. 65, 2018.

[17] M. F. Jenny Hockey, "Ethnography is not participant observation: Reflections on the interview as participatory qualitative research," The Interview: An Ethnographic Approach, pp. 69-87, 2012.

[18] D. L. H. D. K. P. Banten, Profil Hukum Masyarakat Adat dan Kearfian Lokal di Provinsi Banten, Serang: Dinas Lingkungan Hidup Dan Kehutanan Provinsi Banten, 2017.

[19] M. P. M. A. S. Urisha Naido, "Establishing methodological coherence when using observations, stimulated recall interviews and narrative analysis," in World Conference on Qualitative Research, Lisbon, 2018

[20] Mutiarawati, Penanganan Pasca Panen Hasil Pertanian, Bandung: UNPAD Press, 2007. 